\title{
Economics is philosophy, economics is not science
}

\author{
Rupert Read \\ Philosophy Department \\ University of East Anglia \\ Norwich, NR4 7TJ \\ E-mail:r.read@uea.ac.uk
}

\begin{abstract}
An environmentalist's outlook is typically claimed to be based on or even constituted by sound science. It would be natural then for a version of economics based on such insights to claim to be 'even more' scientific than traditional economics. I argue for a conclusion radically opposed to this. I suggest that a genuinely green economics will/should eschew any claims to scientificity. I aim to liberate economics from the albatross of scientific ambition. I urge greens not to try to legitimate their aspirations for the world and for society principally by means of science, but rather to embrace green economics as a point of view that has at its heart an endless love of and faith in life.

I submit that economics is not science, but rather philosophy, and that a Green political philosophy of life will suffer, and not profit, from pretending otherwise.
\end{abstract}

Keywords: Friedman; green; political economy; Mirowski; physics; utility.

Reference to this paper should be made as follows: Read, R. (2007) 'Economics is philosophy, economics is not science', Int. J. Green Economics, Vol. 1, Nos. 3/4, pp.307-325.

Biographical notes: Dr. Read is a Senior Lecturer in Philosophy at the University of East Anglia. His previous publications include The New Wittgenstein (Routledge, 2000, coedited with Alice Crary), Kuhn: The Philosopher of Scientific Revolution (Polity, 2002, coauthored with Wes Sharrock), and Film as Philosophy (Palgrave, 2005, coedited with Jerry Goodenough). He is currently working on Wittgensteinian, Marxist and Green critiques of contemporary 'liberalism', especially the work of John Rawls. He is also a Green City Councilor in Norwich and a Columnist for the Eastern Daily Press newspaper.

\section{Preface}

What is 'Economics'? Is it a science?

I suspect that most economists would answer 'yes', fairly unhesitatingly. I want to suggest, rather, that the heart of Economics is constructed out of what are unrecognised philosophical (and ordinary or 'common-sense') concepts. ${ }^{1}$ 
An environmentalist or ecological/green basis for life typically claims to be based on or even constituted by sound science. ${ }^{2}$ It would be natural for a version of economics based on or that had absorbed such insights to claim to be more scientific than traditional economics. I shall argue for a conclusion radically opposed to this. Without embracing any irrationalism or anti-science attitudes, I shall suggest that a genuinely green economics will/should eschew any claims to scientificity. I aim to liberate economics from the albatross of scientific ambition. I urge Greens not to try to legitimate their aspirations for the world and for society principally by means of science, but rather to be proud of embracing a Green Economics as a point of view, a point of view that we all wish were more widely shared, and that will not be action-able nor even true except insofar as it becomes relatively widely shared. This point of view has at its heart an endless love of and faith in life, in quality of life. For all the merits of physics and biology and indeed environmental science, they do not buttress, let alone constitute, such a point of view. They are in principle orthogonal to it.

I submit that Economics is not science, but rather philosophy, and that a Green political philosophy of life will suffer, and not profit, from pretending otherwise.

\section{Outline}

The present paper is an exploration, a polemic, and a sketch. It pretends to be nothing other or more than these things. However, I believe that the essentials of this paper are quite correct, and the implications of the paper are fundamental, even profound. I want to provide an overview of a set of reasons for thinking that conventional economics systematically misunderstands itself, taking itself to be a science, when in actuality it is a melange of history, maths, psychology, more-or-less-unconscious philosophy and (often highly dangerous) ideology. My suggestion bears significant resemblances to that of the 'institutional economists', followers of Veblen and his school. But it is striking how drastically the institutionalists have been written out of the history of economics and how they have been marginalised in present-day Economics Departments. I hope to play some small role in correcting that injustice.

My suggestion, if correct, could clear the ground for the entry on equal terms or better (into the political-economy debate) of 'Green Economics'. My suggestion also implies a set of warnings about how Green Economics could go wrong.

I essay a basic analysis of why Economics is not science but philosophy (at core), proceeding primarily by means of a ramifying critique of Economics as science.

I first sketch a philosophical critique of mainstream economics working from Positivist Economics through Game Theory to Environmental Economics. I spend some time questioning the philosophical foundations and 'green' credentials of Environmental Economics, in part by means of a very brief history of 'Scientific' Economics. On that basis, I go on to offer a controversial (yet, I would submit, a sympathetic) critique or 'reading' of innovations such as 'green' versions of GDP. I close by developing some more extended reflections on what is wrong with the ambition of a 'Scientific' Economics, and how Green Economics could avoid the pitfalls of scientism by being rather a political economy, a philosophically sound radical alternative to Environmental Economics. Such a Green Economics is not a science: it is a praxis, a project. And any other Economics is in the end a mirage, a collective delusion with potentially utterly catastrophic consequences for the ecosphere. 


\section{3 'Positiv(ist) economics'}

I will begin by briefly noting a curious fact, which may turn out to be of no little significance, especially in relation to what I will go on to discuss in Part II of this paper. The curiosity in question is that the guru of Monetarism, a leading modern and money-centred 'scientific' doctrine of economics, is and was also the leading exponent of 'Positive Economics', that is, of the most central of all 20th century versions of Scientific Economics. I am referring to the hugely famous and influential right-wing economist and thinker, Milton Friedman. He taught Economics as comprehensible in a Positivist fashion, prescinding entirely from the human status of its actors. Over the past generation, the standing of Positivism within Economics has come under increasing challenge, but, as I shall argue further below, there is reason to believe that it has never really been overcome or advanced upon, within 'mainstream' Economics. ${ }^{3}$

Friedman sought to model economic behaviour on the behaviour of natural systems, such as the 'behaviour' of leaves of trees trying to reach the light and maximise the amount of light they receive, regardless of other trees. In forthcoming work, ${ }^{4}$ I analyse in detail the profound failings of Friedman's (in-)famous manifesto for a 'Scientific' Economics, "the methodology of positive economics". For our present purposes, it will be sufficient to point out that Friedman believes that one can adopt utterly unrealistic assumptions in economics (e.g., that people qua economic agents are relevantly similar to leaves, or to billiard balls) and still produce good results. Indeed, such a methodology best yields scientific knowledge and scientifically-grounded predictions about economic systems, according to Friedman. But the truth is, rather, this: We can understand why people do things because we inhabit, vicariously or sometimes literally, their place in the social situation in question. Realistic assumptions, even if as inessential to the natural sciences as Friedman (1953, p.19f.) suggests they are are available and invaluable in the social studies. It is an intellectual error of vast proportion to eschew them. Friedman's suggestion that there is no reason to even try to adopt realistic assumptions in the social studies amounts to a refusal to acknowledge that society is made up of aware and (to some extent unpredictably) responsive human beings, human beings with more or less intimate and indeed 'internal' relations with each other. This means that human beings are not mere atoms: they (we) are, rather, in an important sense part of one another.

There is a difference in kind between the subject-matter of human/social 'sciences' and natural sciences. Failing to recognise the reflexive and through-and-through comprehensible ${ }^{5}$ character of social action, Friedman has simply assumed that economics is a science, in the same way that physics or biology are. He has not provided the slightest reason to believe that this is the best way to look at economics. ${ }^{6}$ This positivist stance simply leaves out so much. Further, this stance tends to militate in due course in favour of the right-wing political philosophy that Friedman espouses, according to which the maximisation of wealth by individuals is rational, natural and unobjectionable. And, unless those individuals choose to prefer otherwise, they can disregard ecosystemic consequences. (Indeed, via a 'mechanism' to which we will return, the very purveying of this picture of humans as Homo economicae ${ }^{7}$ can tend to mould societies in such a way that the picture will come to appear more and more accurate, and the positive economics that elaborates it will appear more and more well-founded.) ${ }^{8}$ 


\title{
4 Game theory
}

Some readers may be thinking that Economics has moved on since Friedman's time. Even if the above criticisms of Friedman of Positivism were found to be just, we have to reckon with the latest in economic theory.

What about the rise of 'game theory', for example? Game theory is the branch of Economics based on the analysis of 'games' such as the famous 'Prisoners' Dilemma', where the prisoners will do best if a prisoner does not confess except when there is a selfish tendency to confess, and hope to 'free-ride' on the other prisoner's not confessing. The 'tragedy of the commons' has been much analysed in these terms.

Here is a crucial philosophical point. The concept 'game' is a concept entirely remote from anything natural-scientisable. ${ }^{9}$ The parameters of games themselves cannot therefore be comprehended by economic theorising. ${ }^{10}$

In any case, without writing a whole (different) paper on the failings of game theory and not attempting here in any serious way its philosophic exposure as merely a variation on the Friedmanian theme, merely a newer subtler scientism, we might at least quickly mention four essential obstacles confronting game theory's claims to overcome the difficulties which sink Positivism in Economics:

1 As implied above, game theory relies on our human understanding, from the inside as it were, of what games (rules, institutions) are. It also encourages us and leads us to forget same!

2 Game theory begs the question against any putative non-scientistic rendition of economics, by presupposing the same old assumptions about selfish individualism, which we have started to question. (See below for more on this topic.)

3 Game theory, if followed through rigorously, yields many disastrous and paradoxical outcomes. Its 'rationality' famously yields numerous patently irrational outcomes.

4 Even if claims (2) and (3) give us some reason to think that 'game theory' may be (partly self-fulfillingly?) succeeding in describing aspects of our sadly irrational current world, it does so not by scientifically analysing games, but by analogising some social phenomena to games. Thus, as intimated in claim (1) above, it begs the following point: it is not in any sense a theory of games, but rather a theoretical game-like structure applied to things that are not games.

\section{The history of economics as a guide to its present - and future}

\begin{abstract}
"But haven't there in fact been some very hopeful developments recently within Economics, developments specifically attuned to the interests of greens, such as the rise of Environmental Economics? Even if there are deep problems with the best of contemporary mainstream economics, can't we learn from and praise these new 'offshoots' from the tree of economic knowledge?"
\end{abstract}

It might be helpful, in contextualising what Environmental Economics is and could be, first to recall a few extremely important moments in the history of Economics well before Friedman's (and game theory's) time. The founders of modern economics, particularly Adam Smith, have often been blamed recently for their responsibility in eventually unleashing turbo-capitalism among others things. But there is reason to believe that this is 
at least to some extent an unfair charge. Whatever Smith's failings, he was (1) a philosopher as much as an economist, not moving away (as many of his inheritors in our age have done) from thinking through the philosophical substructure of economics, albeit (and this is in the end crucially important) in ways more Humean ${ }^{11}$ than (as I would prefer) Wittgensteinian. ${ }^{12}$ Also, he was (2) not given to the tendencies to give over virtually all to the 'invisible hand' of providence and of the market that many contemporary economists (e.g., the many apologists in the Economics profession for 'free-trade') are. Smith was willing to think and look seriously at the sense in which economies are constituted by and for humans, and, not I think unrelatedly to that, he was far less gung-ho about 'liberalisation' (e.g., of capital markets) than most of those alive today who claim him as their 'spiritual guide' or greatest forebear. ${ }^{13}$

Smith believed in economics as an expression of a philosophical vision of humankind and as a tool for improving the welfare of humankind. Over the next century or more, that vital idea of welfare became the economic concept of utility. The key problem from our point of view with the concept of utility is that it tended to involve a slide into scientism. In particular, as Mirowski has eloquently argued in several books, utility as a concept tended implicitly or explicitly to be modelled on the concept of energy in physics. $^{14}$ And thus economists could dream of a social physics, of economics as mechanics. The maximisation of marginal utility ('marginalism') then was a supposed analogue to the maximisation of an energy potential. ${ }^{15}$ But with this striking difference: utility was unmeasurable.

Utility theory was a prime version then of a Smithian effort at maximising welfare. Utility theory and the economics it spawned thereby had something good about it (i.e., simply the internal connection to welfare) and something bad (i.e., the disastrous scientistic trappings of economic theory). These were seen until about the 1930s, when the 'ordinalist revolution' in Economics displaced the then dominant version of (Welfare) Economics which operated by means of trying to assess the utility generated for individuals and societies by various economic transactions, policies, etc. ${ }^{16} \mathrm{My}$ suggestion about this change would be that this was a further disaster for Economics and for the world. The triumph of 'ordinalism' was a triumph of positivism. It directly laid the groundwork for the kind of methodological analysis and prescriptions extremely and influentially promulgated by Friedman (as critiqued above). Ever since the trashing of a 'utility'-based Welfare Economics, positivistic assumptions in Economics have seemed simply natural, as they still do to most conventional and 'mainstream' economists. One thing that Environmental Economics and 'Ecological Economics' do (see especially the discussion of ISEW below) is attempt to recover much of what was lost by way of substantive understandings of what human 'utility' and welfare amounts to, at particular places and times, when the old Welfare Economics was junked. Environmental Economics and 'Ecological Economics' could represent a wonderful widening of the scope of Welfare Economics, to include if you like the true welfare of the whole world including humans. I am concerned that they will not, if they remain connected to the scientistic ambitions that led to the demise (at the hands of the ordinalists) of their 'humbler' predecessor, Material Welfare Economics, in the 1930s and 1940s. 
Concerning Material Welfare Economics, the primary reason for its dismemberment by Ordinalism, is of course, as already mentioned, the problem of unmeasurability. The former did not yield genuine numbers. Numbers are a near sine qua non of scientisable economics, of mathematical economics. However, you cannot literally quantify well-being.

The temptation, to get around this problem, was of course to try to produce quantifications of utility and well-being, which were and will inevitably be derided as arbitrary: What exactly are they quantifying? How is cross-personal quantification of that possible? And so on.

The temptation for sceptics (those who became known as the 'ordinalists') then, was to shift to a straightforwardly positivistic methodology. To abandon the 'assumption' that economic actors are really humans with psychologies, to treat them behaviouristically, to deal merely with their revealed preferences (i.e., what people actually do, which is 'directly observable'); not to attempt to establish the cardinality of their well-being (i.e., how happy or whatever they actually were, or what their quality of life was as a result of their - or indeed others' - economic actions, etc.), but to stop merely with the ordering of their preferences, as 'revealed' in what they actually did/do. (From there, it is a very short road indeed to Friedman's hugely influential methodological statement, which we considered critically above.)

A crucial point here, for our present purposes, is that even if one takes the Economics-as-science idea temporarily on board for the sake of argument, the ordinalist revolution, in taking us further from (what should be) the point of economics (the aiding of human welfare) through its recourse to sheer ordinal preferences, nevertheless made no advance whatsoever in scientific terms! Why? Because as Mirowski (1989, p.364) has argued, the Theory of Revealed Preference (TRP) is really a kind of tautology: "the appeal to revealed preference was an appeal to a vicious circle - observations are used to construct a preference ordering which is then turned around to explain those same observations". Leading economist Paul Samuelson had remarked:

$$
\begin{aligned}
& \text { "Prior to the 1930s, utility theory showed signs of degenerating into a sterile } \\
& \text { tautology. Psychic utility or satisfaction could scarcely be defined, let alone } \\
& \text { measured. Just as we can cancel two from the ratio of even numbers, so one } \\
& \text { could use Occam's razor to cut utility completely from the argument, ending } \\
& \text { with the fatuity: people do what they do."17 }
\end{aligned}
$$

But what Mirowski, following Wong (1978), has laid bare, is that TRP is no different! It is in the end nothing but a more austere positivist and behaviourist rendering of the same idea as utility theory: people do what they do, and that can be described as the carrying out of and the registering by the market of their 'preferences'. (That is a redescription, not an explanation.) Any calculations involving the latter are just as entirely tendentious, based on an ungrounded analogy with mechanics, as were the calculations of the theorists of utility.

Alternatively put, preference-based versions of Economics, which have been so dominant over the past couple of generations, are structurally no superior to and no different from the utility-based models that preceded them. Both are then (unfortunately) based on physics, on the principles of mechanics, of energy. The physics in question is even more dismally out of date now than it already was prior to 'the ordinalist revolution'. If one is going to base one's economics on physics, then surely it should at least be based on physics that is not passé. There should at least be an acknowledgement 
of the kinds of intrinsic limitations on measurability without alteration present in quantum mechanics. At the least, the kind of direction that I have been emphasising in this paper (i.e., my thoughts concerning the dynamic/dialectical reaction of human beings to economic laws and policies) should be begun. But this is not the case; conventional economics is based not only on physics but worse still on defunct physics.

In a bid to foment the ordinalist revolution, Slutsky had argued ${ }^{18}$ that "if we wish to place economic science upon a solid basis, we must make it completely independent of psychological assumptions and philosophical hypotheses". My argument is a kind of inversion of this disastrous manifesto-in-a-nutshell. If we wish to place the study (not the science) of economics on a solid basis, we must make it completely dependent on (or genuinely and thoroughly interdependent with) psychological understanding and philosophical insight. And the psychology in question must not be scientistic psychology. Psychology has been gradually and controversially making inroads back into Economics over the last generation. Unfortunately, most of these are cognitivist in nature. And cognitivism is just as scientistic as behaviourism. They are two sides of the same unhappy coin of a 'scientific psychology'. ${ }^{19}$ Psychology is in almost as bad a state as Economics. It is almost desperate to credentialise itself as a science. So my prescription is a perilous one, but nevertheless I will make it. The huge and long effort to exclude psychology from Economics has been disastrously counter-productive. Instead, we need to return non-scientistically to ordinary psychology (via a non-scientistic philosophical understanding) and to integrate that into economics, in roughly the fashion I indicated regarding Friedman previously. And Economics needs to accept also its fundamentally philosophical nature. Ecomomics should not try to escape its philosophical nature endlessly by adopting tendentious philosophies of science (e.g., positivism) as a means of seeming to transcend substantive philosophical controversy. (It needs to accept, for instance, a broadly Wittgensteinian philosophy of money, such as I will argue for in Part II of this paper.)

\section{The trouble with Environmental Economics}

But do we really need to question the impressive quantificational edifice of Economics? Can it not perhaps help us escape from our predicament in the world today (e.g., from the looming, and perhaps present ecological crisis)? Why not use the tools of Economics to enable a challenge to the way in which the tyranny of the market threatens to deepen the tragedies of the commons that now threaten the very future of civilisation?

This is the promise held out to us by 'Environmental Economics' and other related new sub-disciplines of Economics that aim to find economically sound and powerful ways of internalising into the calculations of economists the goods that have traditionally been left outside of it. 'Environmental Economics' costs what was previously uncosted. It allows the game of Economics, allowing us to assess our world in a 'fairer' way. It can seem to know the price of everything. It raises the prices of most things. In this way, it can surely be used to prevent the wasteful use of resources. It seems to allow a return to and the fulfilment of the Smithian dream in Economics - to use the price system to aid human welfare, without people having to worry about whether what they are doing is right or not. 
But an interesting, difficult and deep question to ask concerning 'Health Economics' and 'Environmental Economics' would be this: does the calculation of 'externalities' internalised, but in terms of money, and indeed of the same old debt-based growth-oriented money that we know all-too-well, ${ }^{20}$ really offer part of the solution? Does it direct us away from a looming iceberg? Or does it only in the end re-arrange the Titanic's deckchairs? ${ }^{21}$

This is particularly pertinent for the project of Green Economics. Is Environmental Economics, through attempting to assign a monetary value to the air, to the oceans and so forth, part of the solution or part of the problem? The project of making 'externalities' internal to the economy seems like it can only be a good and essential, thing, inasmuch as these externalities are wreaking havoc to our world. Surely, we can cost the 'externalities' and bring them within the calculations of businesses, governments, individuals and so on. Then this must be part of the solution, part of what right-thinking, green-minded sectors must want to do?

Let me put the question in another way. Does mainstream Environmental Economics provide a 'psychologically satisfactory' resolution of the neurosis or even psychosis of compulsive eco-destructive behaviour that modern corporations have manifested? $\mathrm{Or}$ does it simply entrench the neurosis? Does it drive it deeper underground, making it appear sane? Is it saner to destroy the atmosphere because it is not included in our costings, or to save it only because it is?

The consolation to one faced by the insanity of conventional Economics is that at least one can defend what one loves by saying, "I'm sorry; one cannot place a monetary value on that that you are threatening or destroying" (be it peace and quiet, love, an unpolluted atmosphere, a mountain-top without a billboard on it, the existence of a certain species, etc.). One can argue that what one is defending is invaluable, or at least incommensurable (not strictly comparable) with the monetarily calculable, the cost-and-benefit-evaluable. The problem with pricing the atmosphere, for instance, is that it takes that vital move away from us. When someone says, "One cannot place a monetary value on that that you are threatening or destroying", the answer is simple: "Oh yes we can!" The calculations then made will, by including what were previously externalities, suggest that what is being threatened should instead be saved. And thus Environmental Economics will sometimes - perhaps often - help us. But at what price? It will help us, only at the cost of taking from us our ultimate tools of self-defence. When Chief Seattle said ${ }^{22}$ that you cannot buy or sell - that you cannot price - the land, the air that we breathe, the rivers, he did not reckon on the imperial reach of economists.

Let me be blunt: the very idea of costing the essentials of life seems to me entirely absurd and repugnant. It is absurd, in that if we are to play this game at all, then the costing in question must come out as infinite and not merely as many trillions of dollars, as it is in Costanza et al..$^{23}$ And it is repugnant, in that the very exercise of thinking how much a breathable atmosphere, for example, should cost, is sick. It is sick in the same kind of way in which it is sick to ask someone what price they would pay not to be tortured.

Let us take an example to explore the implications of questioning the premise of the monetary valuation of 'natural capital' a little further. A key advantage of true carbon rationing (arguably a deep-Green approach) over carbon trading (the main proposed 'solution' to global warming in 'Environmental Economics') is that it is not exploitable by the rich, and it does not give people the impression that they have paid for the right to pollute, and therefore there is nothing that can be said against them for doing what they 
are doing legally, and indeed paying for. Economists who advocate carbon trading and similar devices are complicit in lowering the moral tone of social life. But the key point for our present purposes is not that fact itself. Lowering the moral tone of social life is indirectly linked to the destruction of the ecosphere, for the pricing of everything works powerfully as a device for making morality and love, which are our last defences, seem irrelevant. If I am paying for the privilege of destroying the ecosphere, then who are you to moralise against me doing it?

I do not believe, then, that 'mainstream' Environmental Economics will save us. ${ }^{24}$ It increases the imperial reach of Economics. It takes us further from an Economy (and a society) that works to serve human needs and to express our interconnection with the planet. This results from democratic decisions, rather than suborning those decisions and subjugating those needs to the needs of corporations and the wealthy (those who have more money). It drives the insanity of knowing the cost of everything and the value of nothing into a subterranean place where it starts to look like sanity; this is deeply dangerous. ${ }^{25}$ By costing things that have remained 'externalities' to conventional Economics, it gives environmentalists a poisoned chalice. A Green Economics by contrast must attempt to demystify money, not to mystify it further by making it seem as if money is the ultimate measure of everything. ${ }^{26}$ Green Economics will refuse to monetise the truly valuable, except at most on temporary purely pragmatic grounds. It will also refuse to 'discount' future generations at all.

It might be replied that Environmental Economics tries to avoid positivism, and the temptations of literally quantifying something unquantifiable, and yet to give us a desirably expanded versions of welfare, and that these efforts at least point to the right direction. But can Environmental Economics possibly succeed? I submit that it certainly cannot - unless it allows itself to be seen as the taking up of a point of view, not as the result of 'scientific inquiry'.

\section{A 'case-study': sustainable versions of GDP}

Take the Index of Sustainable Economic Welfare (ISEW) or the Genuine Progress Indicator (GPI). ${ }^{27}$ These, as opposed to GNP/GDP and to some of the monetised indicators and measures central to mainstream Environmental Economics, ${ }^{28}$ should not be understood as measures of real or even of virtual quantities, let alone of money. They are (or should be) very rough attempts, with a kind of roughness that has no possibility of being smoothed out to index the real and intangible things that make life worth living. As Green Economics returns Economics to a task of attempting to index human well-being, it must avoid doing so in a way that implicates absurdities such as the notion that well-being can literally be measured, let alone in a monetised form. ${ }^{29}$ Thus ISEW or GPI will be tools that we can and should use so long as they are not seen as literally measuring something that Economics should be about maximising, in an intellectually imperialistic fashion. ${ }^{30}$ Rather, Economics should always be part of and should attempt to produce a balanced collective life that inevitably involves aspects not measurable, without distortion or neurosis. What price a clear and quiet sky? What price love? What price a liveable climate for the 7th or 777th generation? The ISEW or GPI should remain nothing more than tools to support these ends, never ends in themselves. The use of these indicators must always recognise how limited they are by the very real phenomena of the 
following: pricelessness; value incommensurability (of two things or more being found valuable even by one person (let alone by more than one person) in such a way that their value cannot be subsumed into one overarching value that can be measured); and most elusively and crucially of all, our indissolubility from each other and from our environment and from future generations, our linkedness in an ecosystem that exists over time. If one understands that my welfare is not dissoluble from your welfare and from the welfare of your grandchildren and indeed of worms because there is a sense in which we are all one, then indicators like the ISEW or GPI must be recognised to be at best very vague indicators of something too 'vast' to be measured. Yes, we must try to have ways of assessing how we are doing at sustaining the planet and each other; but how can this be calculated as a figure when the index should now include the contribution being made to the entire future of the biosphere?

ISEW and GPI are worthless as science. They are cooked-up attempts to commeasure incommensurables and to make countries like the USA look less good than they are according to conventional economic measures. I say these things not to criticise. Indeed, I applaud ISEW and GPI. As non-scientific, political ways of stating the kind of point of view from which sane and good people see the world (as a place where GDP and GNP measure things in such a way that, increasingly, the higher they are, the worse many people's lives will be), I think that ISEW and GPI are of considerable use. It is sometimes useful to crudely commeasure incommensurables and to find a quantified scale on which to put the results. But if Green economists use the results to pretend that they are accurately, scientifically measuring people and planet for the first time (if they ape Marxist economics in its aping of 'scientific' method, in its claim to have said or at least successfully modelled how things really are), then they will merely look ridiculous and, in the end, convince no-one.

In sum, these sustainable 'versions' of GDP are not science. They are politics. Environmental Economics will fail as science and will fail our world if it pretends otherwise. Green Economics is and should be a political economy and a philosophic enterprise through and through. (And it profits one nothing to pretend that politics and philosophy are themselves sciences. Philosophy involves one in the understanding of science, not in the act of doing it.)

\section{What then is economics?}

So, to return to the question with which we began: what, in truth, is economics? What is it that we learn if it is not the kind of learning that science is? At its foundation, Economics is philosophy, philosophy that does nothing more than remind us of the ordinary - of our ordinary lives with other people and with non-human-animals and within an ecosphere. This philosophy must be able to reflect intelligently on psychology ${ }^{31}$ and must itself be 'therapeutic', not scientistic. ${ }^{32}$ Green Economics must follow in the initial footsteps of Marxist economics inasmuch as Marx rightly emphasised the centrality of labour, and invited us to focus on production, not merely on consumption (as most neo-classical Economics mostly does) but avoids Marxism's almost complete descent into scientistic catastrophe, and its failure to take our ecosystemic embededdness at all seriously. 
'Scientific Economics' is quite hopeless, has a lot to answer for and is not the route to the society and ecosystem that Greens are trying to create and to 'return' us to. Conventional Economics is a farrago of self-fulfilling propaganda, a cultivated ignorance of the 'philosophy of the ordinary' which I have sketched above. ${ }^{33}$ It is an attempt to replace the open-ended question (and accompanying 'conversation' and indeed struggle) as to what the good life for humans and other creatures is with an inauthentic 'theoryism'. Economics has come to involve a great deal of clever and sophisticated thinking. I am not wishing for a moment to deny for instance the mathematical innovations that it has featured and enjoyed. But these often wonderfully intricate maths should again not be viewed as a theory simply waiting to be applied, to be mapped onto, human phenomena. More crucially still, the danger of taking up the inauthentic attitude of thinking that there are any such things as economic laws, (i.e., anything much-resembling the laws of the natural sciences), is not only that it will obscure from us the welcome tenuousness of the edifice of Economics, built on the forgetting of the human power to revoke money, ${ }^{34}$ but also that it will tend to become a self-fulfilling prophecy. It will 'self-verify'. The more that people believe that Economics is a science, the less likely they will be to exercise their capacity to falsify its theories through their actions, to argue or fight against its conclusions, ${ }^{35}$ to see undeludedly the circularly-defined nature of money and the blunt reality of what we call monetary 'wealth' or to question the premises of individualism and selfishness (Homo economicus) that Economics foists upon us.

I submit that much conventional Economics today rests on the same fragile (broken) basis as Friedman's methodology. It will again be objected in some quarters that 'Game Theory' has arisen as a serious challenge now to the hegemony of positivist Economics. It will be objected that Friedmanian constrained maximisation has given way to the truly rational architecture of game theory as the dominant paradigm. And indeed, it is true that Economics is more internally contested than it was a generation ago. ${ }^{36}$ Within the 'mainstream', however, where Positivism and Game Theory battle it out, it is just not clear to me that there is any significant difference regarding the main axis of my critique in this paper. For 'Game Theory' is seemingly just as wedded to the fundamental ideas that Economics needs to be predictive, that these predictions must come from an individualist model based on the preferences or utility of a selfish social atom (the 'subjective preference theory of value') and that we can develop some kind of social physics as a result. Game Theory, I contend, is just another version of Neo-classical Utilitarianism. ${ }^{37}$ Even those economists who would take Positivism to be superseded must at least admit that Homo economicus is alive and well and living in 'Game Theory'. And, while this paper has not been a sustained direct critique of Homo economicus, ${ }^{38}$ it has sought to show that the scientific ambition that is encoded within all versions of Homo economicus is a flawed and counter-productive ambition.

I do not deny then that there is knowledge and learning in Economics. I do deny that there is science. ${ }^{39}$ Whereas there $i s$ for instance history, there are the rational and living dynamics of thought and action (illumined by those precious rarities, useful pieces of psychology) and there are the political and philosophical projects of demystification that I have endeavoured to indicate or contribute to here. 


\title{
9 Conclusion
}

Cole points out, at the opening of his Economy, Environment, Development, Knowledge, the manner in which leading economists suffer from 'false consciousness' about their discipline, a manner which I have tried to expose in this paper:

\begin{abstract}
"Robert Heilbroner, an eminent economist... argue[s] that " "powerful" economic theory is always erected on powerful sociopolitical visions': visions of 'political hopes and fears, social stereotypes, and value judgements . . . that infuse all social thought.' And these visions structure our understanding, defining what 'we believe we know'. However, on the next page, [he] assert[s] that economic theory is characterized by; "lawful regularities of behaviour, investing it uniquely with the characteristics of a social "science"". How sociopolitical visions are reconciled to lawlike regularities is not explained." (Cole, 1999, p.23)
\end{abstract}

The central point of Cole's (1999, p.32) controversial and insightful book is that "if we assume - that is, believe that either the consumer, the producer or the citizen is determinant in relations of exchange, then we define the system of economic relations". The word believe takes after the fashion of William James: the belief in question is not a cold 'belief-that' such and such is the case; it is an active belief, a believing without which the belief would have no chance of being true.

Compare here Seers's intriguing remark on the same topic:

"Let me first dispose of the question whether any economic theory is, or can be, 'correct'. Students often ask me which theory is right? This is an inappropriate question because there is no objective way of assessing whether any theoretical school is right ... the main ones are self-contained systems, perfectly logical on their own premises ... Empirical tests are not very relevant ... because the objectives ... are derived from the theories ... the crucial questions are: whose interests does a theory serve? How does it serve them?"40

A central point of mine has been that to say something like this need not be to express a fashionable but dangerous or empty relativism or postmodernism or cynicism. What Seers is saying is helpful, because a theory's 'correctness' in economics is internally related to its values, to the interests it serves. The very idea of simple correctness in Economics is absurd because of the nature of the subject matter. Because Economics is only misleadingly regarded as a science and is far more akin to (non-scientistic) philosophy.

There is no 'just stating' the laws or facts of Economics. Every economic or political move, including the moving of stating the alleged facts or laws of economics, affects 'the' laws/facts. Measurement famously affects observation, such as in Quantum Mechanics. But the laws of Quantum Mechanics are unaffected by measurements made in particular instances, whereas in economics the very 'laws' themselves are thoroughly reflexive and utterly historical and are always affected by their use or by their statement.

For all the disasters of the legacy that Adam Smith has left us, we should note that he was at least doing political economy. He looked at the political and economic system with an eye to the general welfare, although for Smith, he was referring chiefly to the welfare of the capitalist. Neo-classical economists, on the other hand, strive to uncover 'the' laws of Economics and pretend to put forward simple truths valid timelessly for all. As Dowd (2004, p.15) puts the point: 
"[N] eoclassical economics does not answer [questions such as "What can and must we do to have the economy serve our human and social and ecological needs?"] from any standpoint. It starts with a set of assumptions and values (muted or taken for granted) and proceeds, using only logic, to assert (through assumptions) what is not so and to follow that with a set of analyses and prescriptions which, although they serve the interests of those holding power in the capitalist status quo, are put forward as equally valid for the society as a whole."

In short, to believe that Economics is a science is already a political move - a move that already places severely in question the very values, the very needs, not to mention the very desired-outcomes, that motivate a Green Economics (or a Green anything else). Taking up the demand for strong sustainability to be the watchword of our society is and must be the taking up of a standpoint. ${ }^{41} \mathrm{We}$ need to take up that standpoint actively and not to pretend that any 'science' will or could save us the bother of having to do so.

Let us imagine a final objection, a last riposte on the part of an advocate of conventional 'scientific' Economics, who is prepared perhaps to acknowledge that Friedman's arguments for his view (for constrained maximisation models) are ridiculous, but who nevertheless refuses to abandon the view itself:

\begin{abstract}
"It is not a priori ridiculous to assume that people do not want to waste resources and want to produce the maximum output for a given input, and it actually does describe the observable data quite well - that is why economics is popular and why people tend to listen to economists. Even in your Green economic system, you will want to organize social units to produce things in the most efficient manner and to produce goods and services that are wanted. You are therefore going to end up with something that looks like a marginal cost function and something that looks like a marginal revenue function, and you will find that the level of production that looks best, is the point where those two functions cross. For all your talk of the way in which human society differs from anything naturally-scientisable, you can't repeal this - any more than you can repeal the laws of thermodynamics. You are also going to end up having to give people an incentive to do unpleasant jobs rather than to enjoy themselves all day, and this will end up looking rather like a wage. Isn't all this going to require something remarkably like conventional economics, to understand it and to work through it?"
\end{abstract}

Clearly, I hope to have headed off a lot of these points. For instance via my brief remarks about what is right in the Austrian economists and via my points about how a society really can organise itself in ways that resist rather than entrench the appeal of a would-be science of the human based on a picture of the human being as a huge consuming mouth (rather than a set of human studies incorporating a picture of the human being as a conserver). People want roads, people want bridges and airports, people want economic growth. But people also want peace, clean air, leisure time, and a better world for their children:

\footnotetext{
“'Humans may prefer' to use fossil fuels rather than solar energy, they may 'prefer' to trade the Earth's biological diversity for consumer goods, but acting on these preferences will change the physical world we live in, probably for the worse. Such an outcome would presumably not be preferred." ${ }^{2}$
}

The word 'probably' here is I think a charming rhetorical understatement. We are among other things talking simply about the survival of the human race. 
So, Green Economics need not assume a positive valuation on 'efficiency', not even ceteris paribus. More efficient exploitation - for example, more efficient mining of (for example) coal - is a bad thing, given the fundamental fact of resource finitude and of finite capacity for absorption of pollution. Green Economics builds these points into its very essence and structure, rather than treating them as externalities that it will try to internalise (as Environmental Economics and most 'Ecological Economics' does).

So, does Green Economics advocate producing goods and services that are wanted? Yes and no. Yes, only insofar as what is apparently wanted is also to some degree needed, and only insofar as what is needed is not obtained in a way that literally costs the Earth.

Will Green Economics produce (roughly) marginal cost and revenue functions? Well, perhaps, sometimes. But again, aren't these just dressed up ways of speaking of or obfuscating a clear discussion of wants and needs and things that one does not really need, and so on? We should start with the needs and capabilities of people and of planet, not - as Veblen saw clearly a century ago - with the unquenchably hungry desires of fantasised social atoms. The maths in Economics, I would suggest, are less akin really to engineering but more to 'economic' cybernetics. These are very particular applied maths. They have very little to do with society, except insofar as society tries to approximate them. This is a final, 'cumulative' illustration of how Economics is not science. The objects of (genuinely) scientific inquiry never try to make themselves conform to scientific laws. The danger of conventional Economics is that it will tend to make true the picture of the human as simply an unquenchable mouth. ${ }^{43}$

The laws of thermodynamics (or any laws of physics) are simply what they are. They apply to (thermodynamically salient) objects, fields, etc. Society by contrast is in the end, or at least potentially, more one even than such fields are. Thus, while interaction between society's 'atoms' is less predictable even than the interaction of particles in chaos theory, on the other hand, there really is no such interaction for there really are no such 'atoms'. We are one. You cannot produce genuine marginal cost and revenue functions, which are separable lines whose crossing-point can be specified, for atoms which are part of each other.

And that is why the problem of incentivising people to do unpleasant jobs need not be remotely the kind of problem that a scientific or mechanistic Economics (implicit in Rawls among many others) would figure it as. There are other options. We could all share the unpleasant jobs. Or we could indeed reward those who do them, who play such a foremost and worthy role in the social organism. Or we could ensure that society is localised and organised into small 'units' where problems of mass rationality (and irrationality) just do not arise.

A Green response to the problem of who is to clean the toilets is (1) to pay toilet cleaners far more than film stars, or (2) for toilet cleaning to be part of everyone's job, or (3) maybe toilet cleaning would be regarded even as a privilege that people would seek out, a task that is for everyone's good, or (4) society might become so small-scaled that this would just not be an issue. There four possible solutions, virtually undreamt of in a system that believes in a labour market as the solution to such problems, such that the worker is a commodity rewarded simply by a wage that is as little as possible, indicate some of the surprising benefits that may follow from a Green Economics that is philosophical and not 'scientific' in its orientation and in its foundations. 


\section{Acknowledgements}

My deep thanks - for crucial help with this paper - to Ken Cole, Tim O'Riordan, Bob Sugden, Phil Hutchinson, Miriam Kennet and Danny Davies. I should stress however that most of these may well disagree still with much of what is in the paper!

\section{Bibliography}

Anderson, V. (1999) Can There be a Sensible Economics?, in M. Scott-Cato and M. Kennet (Eds.).

Ayres, R., van der Bergh, J. and Gowdy, J. (2001) 'Strong versus weak sustainability: economics, natural sciences and "Consilience", Environmental Ethics, Vol. 23, No. 2, pp.155-168.

Cole, K. (1999) Economy-Environment- Development-Knowledge, London: Routledge.

Cooter, R. and Rappoport, P. (1984) 'Were the ordinalists wrong about welfare economics', Journal of Economic Literature, June, Vol. XXII, pp.507-530.

Costanza, R., et al. (1997) 'The value of the world's ecosystem services and natural capital', Nature, Vol. 387, pp.253-260.

Dowd, D. (2004) Capitalism and its Economics, revised and expanded edition, London: Pluto.

Friedman, M. (1953) 'The methodology of positive economics', Essays in Positive Economics, Chicago: U. Chicago Press.

Garrett, Jr., R. (1999) What Do Economists Know?, London: Routledge.

Gowdy, J. and McDaniel, C. (1999) 'The physical destruction of Nauru: an example of weak sustainability', Land Economics, Vol. 75.

Hacking, I. (1999) The Social Construction of What?, Cambridge: Harvard.

Kennedy, M. (1995) Interest and Inflation Free Money, Philadelphia: New Society.

Kuhn, T. (1962) The Structure of Scientific Revolutions, Chicago: U. Chicago Press, 1970.

Mirowski, P. (1988) Against Mechanism: Protecting Economics from Science, Totowa: Rowman and Littlefield.

Mirowski, P. (1989) More Heat than Light: Economics as Social Physics, Cambridge: CUP.

Mirowski, P. (2002) Machine Dreams: Economics Becomes a Cyborg Science, Cabridge: CUP.

Norton, B., Costanza, R. and Bishop, R. (1998) 'The evolution of preferences: why sovereign preferences may not lead to sustainable policies and what to do about it', Ecological Economics, Vol. 24, pp.193-211.

Rawls, J. (1971) A Theory of Justice, Oxford: OUP.

Read, R. (2002) Kuhn, Oxford: Polity, jt. with Wes Sharrock.

Read, R. (forthcoming) There is No Such Thing as Social Science: In Defence of Peter Winch, London: Ashgate, jt. with Wes Sharrock and Phil Hutchinson.

Read, R. (forthcoming) Three Strikes Against the Difference Principle.

Scott-Cato, M. and Kennet, M. (Eds.) (1999) Green Economics, Aberystwyth: Green Audit.

Seers, D. (1983) The Political Economy of Nationalism, Oxford: OUP.

Vatn, A. and Bromley, D. (1993) 'Choices without prices without apology', Journal of Environmental Economics and Management, Vol. 26, pp.129-148.

Winch, P. (1990) The Idea of a Social Science and its Relation to Philosophy, London: Routledge.

Wittgenstein, L. (1958) Philosophical Investigations, London: MacMillan.

Wong, S. (1978) The Foundations of Paul Samuelson's Revealed Preference Theory, Boston: Routledge.

Woodin, M. and Lucas, C. (2004) Green Alternatives to Globalisation, London: Pluto. 


\section{Notes}

1 In claiming this, I draw implicitly on the philosophy of Peter Winch. I would recommend those entirely unfamiliar with Winch's work to look at the works mentioned in this note in order to understand fully what this paper is about. See especially his The Idea of a Social Science and Its Relation to Philosophy (1990). See also my work on Winch on 'social science', especially in my (2002) and my There is no such thing as social science: in defence of Peter Winch (forthcoming).

2 See Ayres et al. (2001), for a particularly-explicit version of this claim.

3 Friedman's (1953) central paper was the definitive statement of economic methodology (of the 'philosophy' of Economics) for about 25 years until the late 1970s. It has not been replaced; but there has seemingly been a gradual shift from the notion of constrained maximisation, which conditions the Friedmanian approach, to Game Theory, which has risen as an alternative 'paradigm' to Friedman. However, it is implicit (and sometimes explicit) in my discussion that game theory and 'rational choice theory' more generally are actually not in any meaningful sense an alternative 'paradigm' to Friedman. The two barely differ. Nor does the recent tendency towards the explicit introduction of psychological ideas into the positivist approach usually make any significant difference either. For the 'rational choice' model and the psychological assumptions in question assume a robotically selfish individual, which is already assumed in Friedman. (I return to these points in my conclusions. And, for anyone who doubts my fundamental idea here, of the way in which the 'agents' in game theory and in psychological experiments in economics are reduced to machines, I strongly recommend a perusal of Mirowski's 'Machines who think versus machines that sell', in his (2002), especially p.549 thereof.)

4 In 'Against Friedman', in my (forthcoming), joint with Hutchinson and Sharrock, I seek among other things to critique Friedman from a Winchian/hermeneutical point of view.

5 In saying this, I do not of course mean to imply that we can always succeed in understanding why someone did something, or even why we ourselves did something. (Note my mention of unpredictability above.) What I mean is that such efforts at understanding proceed as it were 'from the inside', in the case of human beings, in a way which has no analogue, insofar as natural science is concerned. In philosophical terms: human being is the space of reasons, whereas natural science deals with a space merely of causes.

6 It will be objected that the reason Friedman has given us is his claim that economic theories should be judged on the basis of their ability to make predictions. As discussed in Part II of this paper, Friedmanian monetarism for one proved lousy in this regard, for reasons internally related to Friedman's scientism. Monetarism was blind to the way in which human beings as reflexive creatures who understand when they are being constrained and react against it are constitutively ill-suited to being scientifically understood and predicted.

7 This picture is at the heart of the troubling 'social theory' that Economics tends to embody, project or argue for. But from my Wittgensteinian and Winchian point of view, the very wish for a social theory - a theory to explain (the nature of) society - is itself confused. This again is the meaning of my title: Economics as social theory is not science, as it wishes to be, but rather is philosophy - mostly the wrong kind of philosophy. Philosophy as metaphysics of what needs none, as opposed to philosophy as liberating us to return to what we always already understand, especially after the intervention where needed of therapeutic philosophical undelusion: ourselves, as social and linguistic actors who make history, who do society.

8 In other words, Economics and economies are internally and dialectically related. The same is untrue of natural sciences. The state of physics does not affect the state of the physical world.

9 Better than a resort to 'Game Theory' would be to attend to Wittgenstein's beautiful, subtle and pivotal discussion on games. See for instance section 65ff. of his Philosophical Investigations (1958).

10 This point is central to Mirowski's (1988) brilliant critiques of game theory and elsewhere. Game Theory fatally takes for granted the institutions of or constructing the game(s) themselves. 
11 One of the benefits of Smith following David Hume, as compared with later economists who are ignorant of philosophy, is that this gave Smith the notion of sympathy as a central feature of human beings. Thus in Smith, unlike in some of his 'followers', one has something of a built in buttress against a thoroughly selfish model of the individual. For some pertinent discussion, see Dowd (2004, p.29).

12 Smith's Humean model of the self in effect assumes a selfish individual as the fundamental unit, as virtually all contemporary Economics still does. Smith did not see the virtue in 'moralising' Economics. He thought it more effective to work through people's own interests than to proceed via appeals to their moral sense. The idea was to have a price system in which people 'do not need to ask' whether their economic choices are right or wrong. I discuss below what is wrong with this, both in principle and in practice.

13 For discussion of Smith as liberal, but not neo-liberal, see the opening chapter of Woodin and Lucas (2004).

14 See his deep and brilliant discussions in his (1989), (1988) and (2002).

15 The groundwork for this claim is clearly expressed at the opening of Mirowski's (1998) p.24: "[T]he hard core of neo-classical economic theory is the adoption of mid-19th century physics as a rigid paradigm, a hard core it has preserved and nourished throughout the 20th century, even after physics has moved onwards to new metaphors and new techniques". It is worth noting that Austrian economic theory (von Mises and Hayek) does not fit this paradigm. I shall return to this point in Part II of this paper, wherein I make clear that I am rather less distant from Austrian economic theory than from neo-classical theory and positivism. (Though we should bear in mind that Hayek and von Mises et al. continue to assume what Cole (1999, p.33) describes as "the subjective preference theory of value". They take the consumer as the fundamental economic unit, and thereby make dangerous and repugnant political assumptions under the guise of assuming a reasonable account of human nature, very much as the neo-classicals do.)

16 See 'Were the Ordinalists wrong about Welfare Economics' (Cooter and Rappoport, 1984) for a compelling account of how the 'ordinalist revolution' was not normal scientific progress but a would-be scientific revolution, in Kuhn's (1962) sense. The ordinalists did not answer the welfarists' questions; they simply changed the subject. Moreover, it is desperately ironic that it was the 1930s and 1940s that saw the triumph of the ordinalists, for that was the exact historical moment when, in the disaster of the Depression, neo-classicism really should have died (and in a way it did, at the hands not only of Keynes, but simply of history). The historical event that should objectively have buried neo-classical Economics was instead the moment when it became still more deeply entrenched. Until, of course, it became virtually impossible to see its political assumptions and results, see Dowd, 2004, p.94. And perhaps that is partly why ordinalism triumphed at this moment and was only very temporarily eclipsed by Keynesianism. This is because unrestrained capital desperately needed a more effective cloak for its projects. Neo-classical economics, allegedly being science rather than political economy, can pretend that the Depression had nothing to do with its 'scientific' correctness or otherwise.

17 Quoted on p.359 of Mirowski's (1989).

18 In a famous 1915 paper, quoted by Mirowski (1989, p.362).

19 For argument to this conclusion, see the work of Wittgensteinian philosophers of mind and ethnomethodological critics of scientific psychology, such as Sharrock and Coulter.

20 See Part II, for justification of this negative description of money as we know it in contemporary capitalism.

21 One very good reason for not believing that Environmental Economics will save us and that we do not have space to go into at all fully here is that Environmental Economics retains a bias toward monetisable solutions to problems. These solutions include eco-taxation, or carbon-trading, which, while indeed potentially helpful, may obscure the necessity for more radical measures. In the case of climate change, there is some reason to believe that true carbon rationing as opposed to carbon trading may be necessary, to achieve the needed reductions in time to prevent catastrophic climate change. Crudely speaking, Environmental 
Economics, favouring measures like carbon-trading, may stand in the way of Green Economics, which favour measures like the introduction of a non-tradeable carbon-rationing scheme. Thus, Environmental Economics might cause the destruction of our ecosphere by 'crowding out' the more radical approach/measures actually required. (I do not discuss in the present paper the birth of 'Ecological Economics' from Environmental Economics. This is because most 'Ecological Economics' is ambivalent as to whether it is really just souped up Environmental Economics (as is the case with the influential work of David Pearce and Robert Costanza, in my opinion) or whether it has actually made the transition to being Green Economics.)

22 Whether or not he actually said this is immaterial. My point is stronger if he never did. For the power of this rhetoric and of the moral and political claims implicit in it outweighs any mere historical truths.

23 See his (1997). A useful critique of his project, avant la lettre, was provided by Vatn and Bromley (1993).

24 There is a telling analogy here to Rawls' allegedly egalitarian system of political economy. The way in which 'Environmental Economics', through costing everything, risks taking away from one the ability to stand up for the perhaps invaluable, mirrors the way in which Rawls' liberal 'egalitarianism' by making the inequalities produced by the 'difference principle' seem supposedly unobjectionable to anyone, risks taking away from one the right to envy the rich, or to find their continued holdings of wealth unjust. Rawls is quite explicit about this, in Section 87 of $A$ theory of justice (1971). This seems to me a disastrous and perhaps even disgraceful consequence of Rawls. He appropriates the term 'egalitarian' to his theory, and obscures from view that he has done so, absurdly, by providing inequality with a seemingly powerful new 'legitimating' argument. Rawls is no egalitarian. His rationalisation of inequality is only a rationalisation, with no real intellectual power whatsoever. (For more on Rawls in this regard, see my 'Three strikes against the difference principle', forthcoming.)

There is yet a further analogy possible to the way in which conventional economics seems to prove that labourers cannot be exploited by means of capitalists merely profitting from their labour by tracing out a series of 'uncoerced' transactions and preference satisfactions. In the end, mainstream Environmental Economics is perhaps simply taking the arguments of conventional Economics or of Rawls and locking us yet further, deeper, more deludedly into them.

25 For more on this danger, see Anderson's impressive (1999), especially pp.20-23.

26 What is the alternative to monetising or in other ways mensurating everything? Again, it can be simple good old-fashioned politics, such as regulation. You can stop people from chopping down trees in forests that they 'own' not only by pricing carbon or pricing felling rights, but by simply banning logging.

27 See Woodin and Lucas, ibid., p.14.

28 See Cole's (1999, p.112f.) useful discussion of Cost-Benefit analysis. The following quotes that Cole provides I suspect will not-inconsiderably disturb most readers. Here are Helm and Pearce: "The task of environmental economics is ... to place valuations on environmental assets and consequences and, thereby, to develop appropriate policies". As Redclift and Benton remark, "At heart, the neo-classical approach to environmental economics has one aim: to turn the environment into a commodity". My present point might then be put as follows: GPI and ISEW had better not turn out to be nothing more than glorified versions of the (deeply flawed) standard idea of cost-benefit analysis.

29 And here an interesting connection might be made with great religions such as Christianity and Islam which, despite their institutional corruption, have arguably been at heart about human well-being (recall the wonderful slogan of Christian Aid, 'We believe in life before death'). These religions traditionally objected strenuously to usury. Is there not something unjust, harmful and indeed obscene (and even one might say, blasphemous) about the 'creation of wealth' via lending out mere bits of paper? And doubly so, about the 'creation of wealth' via nothing but the creation of debt-based money? (For more, see Kennedy, 1995, p.75f.) See also Part II of the present paper, forthcoming. Here, if we had more space, we should discuss the multiple importance to Greens and, I would suggest, to engaged 
spiritualities in the medium term of redistribution of wealth, and in the longer term of holding the land in common, via a Land Value Tax etc. (Such changes as these will probably in part be possible only via a 'Simultaneous Policy'.)

30 In other words, the charges that the ordinalists understandably (though in the long run disastrously, for us) levied against the material-welfarists (see Cooter and Rappoport, 1984, p.520ff.) can potentially be repeated. Is ISEW supposed to really measure something? If it were supposed to do so, then it would be a principle of organisation for a new would-be-scientific Economics that would claim to be able to measure the whole world, even measuring and valuing parts of the world that conventional Economics cannot reach. ISEW and GPI represent real progress, I say, as the improved inheritors of an abandoned generation of Welfare Economists, so long as we do not fall into the scientistic illusion sketched above, which, needless to say, would hardly lead to Environmental Economics actually being taken seriously as science by conventional Economics, in any case.

31 For more on what I mean here, see p.132 of Harmer's A Green Look at Money, in Cato and Kennet (1999).

32 See Wittgenstein's remarks on philosophy, Philosophical Investigations Sections 108-133.

33 And that I will return to - in Part II.

34 For substantiation of this point, see Part II.

35 To resist, for instance, the laughably biased premises and conclusions of 'The Copenhagen Consensus' and also to resist even a successor project that used an Environmental Economics methodology, and yet failed to promise to do enough to save the Earth as an inhabitable jewel for future generations.

36 If I had more space, I would argue that the fragmentation of Economics over recent generations could easily be seen as grist to my mill. The neo-classical research programme is fragmenting under the vast internal pressures it is under in its endeavours to maintain a science of Economics.

37 In fact, I would be inclined towards putting the point even more strongly, loosely paraphrasing Keynes. Most economists, who think themselves the most practical and down to earth of intellectuals and who think themselves the most grounded scientific men, are intellectually enslaved to some defunct philosopher or methodologist of Economics such as Friedman or Samuelson. In any case, chapter and verse for the failure of most Game Theory to break with or improve significantly upon the fundamental assumptions of neo-classical theory (including constrained maximisation and variations on its theme) can be found in Mirowski's (1988). See especially his 'Is there a mathematical neo-institutional economics?' and 'Institutions as a solution concept in a game theory context'.

38 For which, the reader may be willing to await Hutchinson's forthcoming work.

39 By this point, the reader may be anxious to know more about what precisely I mean by 'science'. My full answer is in my (2002).

40 Seers, 1983; quoted on Cole, p.32.

41 For discussion and support of strong sustainability, as opposed to the weak sustainability of 'Environmental Economics', of Rawls, etc., see Gowdy and McDaniel (1999).

42 Ayres et al. (2001). See also Norton et al. (1998).

43 An illustration of this is the worrying fact that undergraduate students of Economics tend to behave more as rational self-interested utility maximisers than do others, in economic experiments. 